Bazo, L, Cukanova, M., Markovicova, L., \& Steinhauser, D. (2019). The Impact of Institutional Environment on Slovak Enterprises and the Institutional Hysteresis Effect. Journal of Competitiveness, 11(3), 35-52. https://doi.org/10.7441/joc.2019.03.03

\title{
THE IMPACT OF INSTITUTIONAL ENVIRONMENT ON SLOVAK ENTERPRISES AND THE INSTITUTIONAL HYSTERESIS EFFECT
}

\section{- Ladislav Bazo, Miroslava Cukanova, Laura Markovicova, Dusan Stein- bauser}

\begin{abstract}
In recent years, a decline in competitiveness and in the quality of the business environment measurements has been reflected in the Slovak Republic, as noted, for example, in the assessments of the World Bank and the World Economic Forum, as well as in the business environment index (BEI from Business Alliance of Slovakia PAS), data from which we have used in our research. A multiple regression analysis along with the correlation analysis confirmed our assumption that in the Slovak Republic a state of institutional hysteresis exists. The hysteresis effect indicates rigidity despite the economic recovery, not restoring the original balance after a certain failure in the economic process. In our case, many external environment subindeces tend to decline while macroeconomic variables (employment, value added, R\&D expenditures, revenues from corporate taxes) grow. On the other hand, the internal factors of a company, through which it itself affects the environment, such as the level of liquidity or innovation, is growing. We conclude that the companies we examined have adapted. The process of improving the assessment of the country (corruption, law enforcement, equality before the law, functioning of the judiciary) will become much more expensive over time. The result of this change should be an entrepreneurial environment in which the entrepreneur does not have to deal with the ongoing optimization of taxes and levies, a condition which in the long run would lead to the economic recovery in the Slovak Republic and to improvements in competitiveness.
\end{abstract}

Keywords: bysteresis effect, institutional environment, Slovak republic, business environment index, perception of institutional quality

JEL Classification: B52, F63; O10

Received: October, 2018

1st Revision: May, 2019

Accepted: June, 2019

\section{INTRODUCTION}

A high-quality business environment is one of the basic prerequisites for the healthy economic development of a country. The competitiveness of enterprises is largely determined by the en- 
vironment in which they develop their business activities. In Slovakia, there prevails a longstanding opinion among entrepreneurs, in simple terms a "poor business environment," which hampers business activities. On the other hand, if we look at the evolution of the economy, the data demonstrate a discrepancy between the real results achieved and the opinions of the business entities in Slovakia. Such a phenomenon is referred to as a hysteresis effect in the economic theory, indicating the effects of rigidity despite the economic recovery, in other words, not restoring the original balance after a certain failure in the economic process. This manifestation in the economic theory is mostly associated with unemployment, which has inspired us to examine this phenomenon (Martincová, 2005). Based on the long-term monitoring of statistical and macroeconomic data monitoring the economic performance of the Slovak Republic, we decided to identify the effect of hysteresis in the business (institutional) environment perception in the Slovak Republic.

\section{THEORETICAL BACKGROUND}

The institutional environment or the institutional framework depends on the set up of individual institutions and organizations. For this reason, we have employed institutional economic theory and, especially, the new institutional theory as the basis for our article. These theoretical schools devote particular attention to examining contractual relationships and transactions which are concluded between economic subjects. As the economic reality (unlike the theoretical construct of the neoclassical school) nearly does not meet the conditions for perfect competition, the transactions are threatened by failure and breach of contracts. Therefore, these transactions are secured, which is linked to the creation of transaction costs. The founder of transaction cost theory was Coase (1937), who claims that these costs determine even the very existence of a company (more information about new institutional economic theory e. g. Liška, et al. (2011). The individual transaction ensuring instruments are called governance structures (Williamson, 1990), with marketing, legal, and security services as examples of these costs. More efficient national economies have an environment characterized by a lower level of transaction costs.

For this reason, it is necessary to measure the amount of transaction costs. Wang (2003) characterized 7 groups of quantification methods, while the direct method of quantification of transaction costs was developed by Wallis \& North (1986). These authors estimated the amount of transaction costs from 1870 to 1970 in the US economy through the performance of transaction sectors (finance, insurance, real estate, wholesale trade and retail trade) and non-transaction industries (using a methodology that estimated the amount of transaction costs in this sector, e. g. through a share of employment in this sector that secures transactions, such as lawyers, controllers, or management). In this model, transportation is considered as a production cost, not a transaction cost. Okruhlica (2013) measured transaction costs indirectly using an index of competitiveness. Nations with lower transaction costs are simply more competitive. Another way of measurement is to use financial market indicators such as credit derivatives (Steinhauser, 2015). Steinhauser assumed that a lower risk premium on sovereign credit default swaps could be associated with an environment with a lower level of transaction costs.

According to North's theory of path dependence, changes in the institutional environment are 
slow and difficult (Liška et al., 2011). Among institutions there exists a process of interaction and learning. For this reason, it is necessary to start with changes in single institutions which will later influence the institutional environment as a whole. Due to the rigidity of changes in the institutional environment, we assume that economic subjects are able to adapt to deteriorating conditions and generate positive economic performance. For this reason, we anticipate the existence of institutional hysteresis in the Slovak Republic. The process of the hysteresis effect means that economic subjects consider a long-term negative status in the environment as a normal state (Martincová, 2005).

Rialp-Criado \& Komochkova (2017) demonstrate a strong link between the business environment and business activities. These authors conclude that increasing the export intensity of Chinese exporting SMEs depends on the alignment of their technology innovation strategy with the local institutional environment. The authors investigated the effect of, inter alia, expenditures on research and the development of the degree of internationalization (DOI), and they unexpectedly found a negative impact: "Thus, the more that Chinese exporting SMEs can align their technological-innovation strategy with the local institutional context, the more they can intensify their degree of export intensity." Investigating corruption, the authors found that with an increase in corruption, DOI falls. A strong relationship between the business environment and business activities is also confirmed by Eling \& Schaper (2017), who argue that the conditions of the economic, capital and insurance markets significantly determine the effectiveness of European life insurance companies. More challenging business conditions as a trend in the external business environment have resulted in an increase in total factor productivity. Harc \& Basarac (2016) investigated the impact of the business environment on employment in SMEs in the EU member states. Lower costs of starting a business and stronger macroeconomic conditions, such as higher industrial production, higher investment rates and lower labor costs, would have a positive impact on employment in small and medium-sized enterprises in the European Union. The research and analysis of Torkkeli et al. (2019) on the institutional forces impacting entrepreneurship has found that the institutional environment of a country can either significantly drive or prevent certain types of entrepreneurial activity.

On the other hand, a number of authors confirm the negative impacts of the business environment on business activity and productivity. Examining the impact of the investment climate on business productivity in Vietnam, Trung \& Kaizoji (2017) concluded that gaps in the investment environment have a damaging effect on productivity and the natural competition between firms. Although only the abstract of the paper was available to us, this was very interesting information for our purpose, i.e. a deteriorated institutional environment in the form of bad regulation is compensated for by corruption. However, these authors consider corruption a serious problem. Institutional reforms, including ensuring efficiency in the provision of public goods and services and the fight against corruption, are therefore necessary measures in developing countries in order to support business activities. A similar conclusion was reached by Nguimkeu (2016), who argues that regulation costs, corruption, credit constraints, and infrastructure shortages negatively affect the gross margins of companies. Using econometric methods, the author explored Cameroon's economy: “[R]egulation costs, poor institutions, credit constraints and lack of infrastructure negatively and significantly affect the gross margins of firms. Although the 
competition of the informal sector is perceived by formal entrepreneurs as a major constraint to their activities, our estimates show that this factor positively affects the performance of formal firms, possibly by indirectly stimulating their efforts as suggested by various theories (Nguimkeu, 2016)."

\section{RESEARCH OBJECTIVE AND METHODOLOGY}

The aim of our study is to demonstrate the impact of the institutional environment, which we measure selected macroeconomic variables in the Slovak Republic through the business environment index (BEI). Our goal is also to verify our assumption that macroeconomic indicators in the Slovak Republic are improved with the process of institutional hysteresis despite the deterioration of institutional environment in many areas. Our endeavor is not to justify the deterioration of the institutional framework, but to point out its existence and the need to overcome the hysteresis in the Slovak Republic. In order to achieve this aim, we mainly used quantitative methods (descriptive, correlation and multiple linear regression analysis) of scientific work, which were interpreted by the literature of the authors Lukáčik et. al. (2011), Pacáková et al. (2009). The analyses were calculated and graphically represented using Microsoft Excel and Gretl.

As dependent variables, we used the employment in thousands of persons (Employ_t), value added in million EUR (VA_milEUR), corporate expenditures on research and development in thousands EUR (RD_Corp_tEUR), and revenues from corporate taxes in thousands EUR (Corp_Tax_tEUR) for the years 2002-2016. The dependent variables were compiled from the databases of the Statistical Office of the Slovak Republic (ŠÚ SR), the Ministry of Finance of the Slovak Republic (MF SR) and the Financial Administration of the Slovak Republic (FS SR). From our point of view, these compositions of macroeconomic indicators enable us to indirectly interpret the microeconomic performance of enterprises. Macroeconomic variables are the aggregated results of enterprises at microeconomic level. The institutional environment is made up of a set of formal, informal institutions and organizations, while the causal relationship between the institutional and macroeconomic environment of enterprises has been demonstrated by previous studies by Kittová \& Steinhauser (2017). Authors indirectly quantified the amount of transaction costs in the environment by using the index of economic freedom of the Heritage Foundation. One of the transaction costs is corporate governance, with authors assuming that: "However, in a high-quality institutional environment characterized by a low level of transaction costs, which means with a higher index of economic freedom, the implementation of corporate governance is less costly (Kittová \& Steinhauser, 2017)." The analysis was applied to a large sample of observations on countries rated by the Index of Economic Freedom, and this presents a limitation of the previous study. This way, we cannot prove the institutional hysteresis, which we assume in the Slovak Republic. For this reason, we have decided to use the detailed BEI, which provides enough observation and has been developed by the Business Alliance of Slovakia (PAS).

The base period for calculating business environment index (BEI) with reference value of 100 points was 1 July 2001. The analysis of business environments gives an answer to economic policy makers, where their efforts are positive and where it is appropriate to take key measures 
to improve. Methodology of BEI was chosen as the following: "The index has three rating categories. The first category has 12 items and monitors the development of the legislative and regulatory environment in the Slovak Republic. Among the individual items are for example business and tax legislation, fees and investments, law enforcement, market regulation. The second category has 11 items and summarizes the impacts of other external macroeconomic factors on businesses. It monitors for example price stability, currency exchange movements, fiscal policy, and infrastructure level. The third category of BEI has 10 items and takes into account the contribution of individual enterprises to the development of the business environment. Each of the 33 items has its own weight, so the index represents the weighted arithmetic mean of the changes of individual items (PAS, 2013 in Conorto et al., 2014)”.

Business Alliance of Slovakia (PAS) and with the Executive Director Peter Kremský represent a partner of the Global Competitiveness Report of the World Economic Forum (Schwab \& World Economic Forum, 2018). Other PAS activities include the development of BEI, which is based on responses given by Slovak entrepreneurs. Here we see the greatest limitations of our research, namely subjectivity. Based on the observations of long-term data, we cannot exclude the political sentiment or general sentiment of the involved entrepreneurs. For this reason, we have added figure of the Fraser Institute Ecomic Freedom (The Fraser, 2018).

Table 1 shows the characteristics of independent variables English index- and items- translations were transferred directly (direct citations) from the source document PAS (2017), which were delayed in the time series by one year (lag_1).

Tab. 1 - Characteristics of independent variables. Source: PAS (2017)

\begin{tabular}{|l|l|}
\hline 1_Legal_framework_1 & $\begin{array}{l}\text { The influence of main components of the legislative and } \\
\text { regulatory framework on business }\end{array}$ \\
\hline Political_system_1 & Functionality of political system in the country \\
\hline Regulation_contracts_1 & Commercial law / Business legislation \\
\hline Regulation_labor_1 & Labor Law \\
\hline $\begin{array}{l}\text { Regulation_taxes_investi- } \\
\text { tions_1 }\end{array}$ & Legislation on taxes, fees and investment \\
\hline Regulation_social_levies_1 & Legislation on payroll taxes \\
\hline Regulation_market_1 & Market regulation, legislation on economic competition \\
\hline $\begin{array}{l}\text { Regulation_insolvency_execu- } \\
\text { tions_1 }\end{array}$ & Bankruptcy and execution legislation \\
\hline Regulation_clarity_stability_1 & Comprehensibility, applicability, stability of legislation \\
\hline Equality_before_law_1 & Acceptance of subject equality before the law \\
\hline Enforceability_of_law_1 & Law enforcement, judicial effectiveness \\
\hline $\begin{array}{l}\text { Functionality_gov_struc- } \\
\text { tures_1 }\end{array}$ & $\begin{array}{l}\text { Functionality of public institutions (register courts, tax } \\
\text { offices, ...) }\end{array}$ \\
\hline Regulation_foreign_trade_1 & $\begin{array}{l}\text { Regulation of market entry/exit (licensing, certificates, } \\
\text { duties) }\end{array}$ \\
\hline
\end{tabular}




\begin{tabular}{|c|c|}
\hline $\begin{array}{l}\text { 2_Impact_external_factors_ } \\
\text { on_firm_1 }\end{array}$ & $\begin{array}{l}\text { The influence of other significant external macro. factors } \\
\text { on business }\end{array}$ \\
\hline Economic_policy_1 & State economic policy, access to information \\
\hline Bureaucracy_1 & Presence of bureaucracy \\
\hline Corruption_1 & Corruption in public institutions \\
\hline Economic_crime_1 & Presence of unfair competition, crime, lawlessness \\
\hline Efficiency_State_Gov_1 & Efficiency of state economy, access to state aid \\
\hline Price_stability_1 & Price stability \\
\hline Exchange_rate_stability_1 & Stability and predictability of the EUR exchange rate \\
\hline Financial_resources_1 & Access to financing (loans, capital markets, etc.) \\
\hline Infrastructure_1 & $\begin{array}{l}\text { Level of infrastructure (transportation, telecommunica- } \\
\text { tions, etc.) }\end{array}$ \\
\hline Quality_availability_inputs_1 & Quality and accessibility of primary inputs, labour force \\
\hline Reliability_bus_partners_1 & Credibility, financial discipline of business partners \\
\hline $\begin{array}{l}\text { 3_Impact_firm_on_environ- } \\
\text { ment_1 }\end{array}$ & $\begin{array}{l}\text { The influence of our company on quality of business } \\
\text { environment }\end{array}$ \\
\hline Fulfilling_vision_goals_1 & Accomplishing company vision, plans \\
\hline $\begin{array}{l}\text { Perform_productivity_profit- } \\
\text { ability_1 }\end{array}$ & Company performance, productivity, profitability \\
\hline Management_system_1 & Management system, human resources management \\
\hline $\begin{array}{l}\text { Investment_tech_develop- } \\
\text { ment_1 }\end{array}$ & $\begin{array}{l}\text { Investment and technological development, quality of } \\
\text { production }\end{array}$ \\
\hline Liquidity_cash-flow_1 & Liquidity, cash-flow, meeting company's obligations \\
\hline Appeal_to_bus_partners_1 & $\begin{array}{l}\text { Behaviour (Conduct) towards business partners, solving } \\
\text { the problems, conflicts }\end{array}$ \\
\hline $\begin{array}{l}\text { Employ_renum_soc_pro- } \\
\text { gram_1 }\end{array}$ & Employment, remuneration system, social program \\
\hline Natural_environment_1 & Relation to the environment \\
\hline $\begin{array}{l}\text { Transp_public_perform_im- } \\
\text { age_1 }\end{array}$ & Information openness, appearance in the public, image \\
\hline Charity_1 & Support for a local region, charity \\
\hline
\end{tabular}

We applied the correlation analysis to all components of BEI. Negative correlation coefficients represent the range from a moderate to a strong relationship (we worked with the correlation coefficient with an absolute value above 0.4), and indicate an institutional hysteresis. A similar assumption has also been made for the regression analysis. Our regression equation will have a positive sign by the estimated parameters. In case of negative signs, we confirm our assumption that there is an institutional hysteresis in Slovakia. In case of the regression analysis, we have only worked with three BEI subindices to limit the number of variables in the model. The regression equations were: 
$Y=$ const $+b_{1}^{*} x_{1}+b_{2}^{*} x_{2}+u$

Our hypothesis is formulated as: With a better assessment of the institutional environment perception through BEI (at the same time we anticipate a decline in transaction costs in the economy), we expect an improvement in employment, value added, science and research expenditures and an increase in revenues from corporate taxes to the state budget of the Slovak Republic.

\section{RESULTS AND DISCUSSION}

Table 2 describes the input data using descriptive statistics, specifically using the indicators mean (Mean), standard deviation (St. Dev.), coefficient of kurtosis (Kurt.), coefficient of skewness (Skew.), minimum values (Min.) and maximum values (Max). The total number of observations (N) is 15 . The negative value of kurtosis coefficient indicates the negative, left-handed asymmetric distribution of years, which means that there are more years with an index value less than the average. In case of a positive value, it presents the opposite. A high coefficient of kurtosis indicates that there are extreme values in the file exceeding the standard normal distribution.

Tab. 2 - Descriptive statistics 2002-2016. Source: own processing by ŠÚ SR, 2017; PAS, 2017; MF SR, 2005; FS SR, 2017

\begin{tabular}{|l|l|l|l|l|l|l|}
\hline N =15 & Mean & St. Dev. & Kurt. & Skew. & Min. & Max. \\
\hline Employ_t & 2313.78 & 104.62 & -0.46 & -0.33 & 2127.00 & 2492.10 \\
\hline VA_milEUR & 57104.36 & 12689.90 & -0.86 & -0.65 & 33730.65 & 72933.02 \\
\hline RD_Corp_tEUR & 154843.01 & 68737.20 & -0.75 & 0.81 & 88534.72 & 296210.00 \\
\hline Corp_Tax_tEUR & 1744093.73 & 625169.04 & 0.66 & 0.73 & 926386.65 & 3187395.40 \\
\hline 1_Legal_framework_1 & 72.41 & 29.58 & -1.58 & -0.38 & 25.40 & 105.26 \\
\hline Political_system_1 & 64.09 & 35.90 & -1.86 & -0.05 & 16.07 & 106.63 \\
\hline Regulation_contracts_1 & 98.01 & 23.17 & -0.80 & -0.15 & 58.56 & 133.41 \\
\hline Regulation_labor_1 & 80.42 & 33.38 & -1.08 & -0.08 & 28.98 & 130.57 \\
\hline $\begin{array}{l}\text { Regulation_taxes_investi- } \\
\text { tions_1 }\end{array}$ & 105.89 & 41.02 & -0.83 & -0.44 & 35.35 & 162.64 \\
\hline Regulation_social_levies_1 & 101.99 & 43.86 & -1.01 & -0.24 & 32.29 & 165.81 \\
\hline Regulation_market_1 & 81.62 & 25.11 & -1.53 & -0.37 & 40.52 & 111.63 \\
\hline $\begin{array}{l}\text { Regulation_insolvency_ex- } \\
\text { ecutions_1 }\end{array}$ & 84.80 & 19.01 & -1.18 & -0.64 & 49.92 & 102.61 \\
\hline $\begin{array}{l}\text { Regulation_clarity_stabil- } \\
\text { ity_1 }\end{array}$ & 53.44 & 29.26 & -1.59 & 0.02 & 12.53 & 96.69 \\
\hline Equality_before_law_1 & 57.41 & 33.53 & -1.78 & -0.14 & 9.78 & 99.74 \\
\hline Enforceability_of_law_1 & 45.15 & 32.67 & -1.55 & 0.21 & 4.89 & 98.34 \\
\hline $\begin{array}{l}\text { Functionality_gov_struc- } \\
\text { tures_1 }\end{array}$ & 97.22 & 12.30 & -0.80 & -0.59 & 75.71 & 113.96 \\
\hline Regulation_foreign_trade_1 & 146.10 & 23.24 & -0.30 & -1.14 & 101.17 & 165.20 \\
\hline $\begin{array}{l}\text { 2_Impact_external_fac- } \\
\text { tors_on_firm_1 }\end{array}$ & 93.24 & 23.65 & -1.25 & -0.49 & 53.62 & 121.51 \\
\hline Economic_policy_1 & 101.75 & 32.58 & -1.19 & -0.08 & 50.48 & 150.08 \\
\hline
\end{tabular}




\begin{tabular}{|l|l|l|l|l|l|l|}
\hline Bureaucracy_1 & 52.04 & 30.93 & -1.63 & 0.07 & 10.44 & 98.03 \\
\hline Corruption_1 & 52.61 & 30.31 & -1.66 & 0.10 & 12.80 & 98.03 \\
\hline Economic_crime_1 & 73.59 & 25.44 & -1.63 & -0.40 & 33.25 & 99.13 \\
\hline Efficiency_State_Gov_1 & 54.12 & 33.35 & -1.83 & -0.05 & 9.68 & 99.25 \\
\hline Price_stability_1 & 89.65 & 22.27 & -1.50 & -0.52 & 56.42 & 114.55 \\
\hline Exchange_rate_stability_1 & 121.10 & 10.24 & 1.18 & 1.23 & 107.88 & 144.71 \\
\hline Financial_resources_1 & 191.57 & 43.34 & -0.03 & -0.77 & 105.12 & 250.84 \\
\hline Infrastructure_1 & 143.05 & 19.06 & -0.05 & -1.08 & 103.33 & 162.72 \\
\hline $\begin{array}{l}\text { Quality_availability_in- } \\
\text { puts_1 }\end{array}$ & 111.87 & 10.23 & -0.22 & 0.35 & 94.38 & 131.13 \\
\hline Reliability_bus_partners_1 & 94.15 & 34.50 & -1.39 & -0.39 & 39.64 & 136.29 \\
\hline $\begin{array}{l}\text { 3_Impact_firm_on_envi- } \\
\text { ronment_1 }\end{array}$ & 215.29 & 60.86 & -1.11 & -0.69 & 106.81 & 284.10 \\
\hline Fulfilling_vision_goals_1 & 216.52 & 54.00 & -0.62 & -0.96 & 109.86 & 268.17 \\
\hline $\begin{array}{l}\text { Perform_productivity_prof- } \\
\text { itability_1 }\end{array}$ & 193.09 & 40.59 & -0.35 & -0.88 & 110.96 & 242.05 \\
\hline Management_system_1 & 187.38 & 46.97 & -1.08 & -0.45 & 105.79 & 248.01 \\
\hline $\begin{array}{l}\text { Investment_tech_develop- } \\
\text { ment_1 }\end{array}$ & 238.15 & 78.50 & -1.36 & -0.40 & 108.32 & 339.79 \\
\hline Liquidity_cash-flow_1 & 214.99 & 56.86 & -0.82 & -0.92 & 106.86 & 263.33 \\
\hline Appeal_to_bus_partners_1 & 201.90 & 62.84 & -1.39 & -0.39 & 101.53 & 281.38 \\
\hline $\begin{array}{l}\text { Employ_renum_soc_pro- } \\
\text { gram_1 }\end{array}$ & 178.23 & 40.80 & -1.07 & -0.84 & 104.41 & 214.72 \\
\hline Natural_environment_1 & 266.57 & 116.17 & -1.32 & 0.11 & 104.52 & 454.61 \\
\hline $\begin{array}{l}\text { Transp_public_perform_im- } \\
\text { age_1 }\end{array}$ & 309.35 & 138.32 & -1.43 & -0.06 & 105.92 & 513.71 \\
\hline Charity_1 & 222.48 & 67.76 & -1.32 & -0.58 & 106.80 & 302.10 \\
\hline
\end{tabular}

The following table 3 includes all reforms that were implemented in the Slovak Republic from 2009 to 2014, and are closely linked to the development of our time series. These reforms influence the institutional environment, which we monitor through Measuring Business Regulations, Doing Business (WBG, 2017). Most reforms make business easier, however, reforms in 2014 marked as negative (-) make business more difficult and have a negative influence on the institution environment in the Slovak Republic.

Tab. 3 - Business Reforms in the Slovak Republic. Source: WBG (2017)

\begin{tabular}{|l|l|}
\hline Year & Description of reform \\
\hline 2016 & $\begin{array}{l}\text { The Slovak Republic simplified the process of starting a business by introducing } \\
\text { court registration at the one-stop shop. }\end{array}$ \\
\cline { 2 - 2 } & $\begin{array}{l}\text { The Slovak Republic made paying taxes easier for companies by introducing an electron- } \\
\text { ic filing and payment system for VAT_-and made paying taxes less costly by reducing } \\
\text { the corporate income tax rate and making medical health insurance tax deductible. At } \\
\text { the same time, the Slovak Republic reduced the limit on losses carried forward. }\end{array}$ \\
\hline
\end{tabular}




\begin{tabular}{|c|c|}
\hline \multirow[t]{2}{*}{2015} & $\begin{array}{l}\text { The Slovak Republic made starting a business easier by reducing the time needed to } \\
\text { register with the district court and eliminating the need (and therefore the fee) for } \\
\text { the verification of signatures by a notary public. }\end{array}$ \\
\hline & $\begin{array}{l}\text { The Slovak Republic improved its credit information system by implementing a new } \\
\text { law on the protection of personal data. }\end{array}$ \\
\hline \multirow{3}{*}{2014} & $\begin{array}{l}\text { The Slovak Republic made starting a business more difficult by adding a new proce- } \\
\text { dure for establishing a limited liability company. (-) }\end{array}$ \\
\hline & $\begin{array}{l}\text { The Slovak Republic made paying taxes more costly for companies by increasing the } \\
\text { corporate income tax rate and by adjusting land appraisal values. }(-)\end{array}$ \\
\hline & $\begin{array}{l}\text { The Slovak Republic reduced the maximum cumulative duration of fixed-term con- } \\
\text { tracts, reintroduced the requirement for third-party notification when terminating } \\
\text { an employee, reintroduced mandatory severance pay for workers with more than } 2 \\
\text { years of service in the company and increased the minimum wage. }\end{array}$ \\
\hline \multirow{5}{*}{2013} & $\begin{array}{l}\text { The Slovak Republic made starting a business easier by speeding up the processing } \\
\text { of applications at the one-stop shop for trading licenses, income tax registration and } \\
\text { health insurance registration. }\end{array}$ \\
\hline & $\begin{array}{l}\text { The Slovak Republic made paying taxes easier for companies by implementing elec- } \\
\text { tronic filing and payment of social security and health insurance contributions. }\end{array}$ \\
\hline & $\begin{array}{l}\text { The Slovak Republic made enforcing contracts easier by adopting several amend- } \\
\text { ments to the code of civil procedure intended to simplify and speed up proceedings } \\
\text { as well as to limit obstructive tactics by the parties to a case. }\end{array}$ \\
\hline & $\begin{array}{l}\text { The Slovak Republic improved its insolvency process by redefining the roles and } \\
\text { powers of creditors and trustees, strengthening the rights of secured creditors and } \\
\text { redefining rules for the conversion of restructuring into a bankruptcy proceeding. }\end{array}$ \\
\hline & $\begin{array}{l}\text { The Slovak Republic increased the maximum duration of fixed-term contracts, } \\
\text { eliminated notification requirements to third parties in case of redundancy dismiss- } \\
\text { als and reduced redundancy costs. }\end{array}$ \\
\hline 2012 & $\begin{array}{l}\text { The Slovak Republic improved its credit information system by guaranteeing by law } \\
\text { the right of borrowers to inspect their own data. }\end{array}$ \\
\hline 2011 & Slovak Republic reduced the maximum duration of fixed-term contracts. \\
\hline 2010 & $\begin{array}{l}\text { The Slovak Republic reduced the time for trading across borders by introducing } \\
\text { more electronic systems for customs administration. }\end{array}$ \\
\hline 2009 & $\begin{array}{l}\text { The Slovak Republic made starting a business easier through its one-stop shop, } \\
\text { which merged } 4 \text { procedures into } 1 \text { and reduced costs. }\end{array}$ \\
\hline
\end{tabular}

Table 4 shows the correlation matrix among all components of the BEI, and also macroeconomic and statistical data. Positive signs of the coefficients were mostly confirmed by the third subindex (the influence of our company on the quality of the business environment). It means that with the increase of the value of this subindex, the performance of the companies has also proportionally increased, which reflects the increase of dependent variables. 
Tab. 4 - Correlation matrix. Source: own processing by ŠÚ SR, 2017; PAS, 2017; MF SR, 2005; FS SR, 2017

\begin{tabular}{|c|c|c|c|c|}
\hline $\mathrm{N}=15$ & Employ_t & $\begin{array}{l}\text { VA_mil } \\
\text { EUR }\end{array}$ & $\begin{array}{l}\text { RD_Corp_t } \\
\text { EUR }\end{array}$ & $\begin{array}{l}\text { Corp_Tax_t } \\
\text { EUR }\end{array}$ \\
\hline 1_Legal_framework_1 & -0.642 & -0.846 & -0.950 & -0.699 \\
\hline Political_system_1 & -0.703 & -0.906 & -0.912 & -0.702 \\
\hline Regulation_contracts_1 & -0.259 & -0.468 & -0.848 & -0.442 \\
\hline Regulation_labor_1 & -0.507 & -0.709 & -0.895 & -0.599 \\
\hline Regulation_taxes_investitions_1 & -0.352 & -0.539 & -0.890 & -0.532 \\
\hline Regulation_social_levies_1 & -0.357 & -0.574 & -0.901 & -0.517 \\
\hline Regulation_market_1 & -0.574 & -0.794 & -0.945 & -0.651 \\
\hline Regulation_insolvency_executions_1 & -0.625 & -0.817 & -0.962 & -0.712 \\
\hline Regulation_clarity_stability_1 & -0.772 & -0.948 & -0.892 & -0.763 \\
\hline Equality_before_law_1 & -0.715 & -0.915 & -0.919 & -0.722 \\
\hline Enforceability_of_law_1 & -0.778 & -0.962 & -0.863 & -0.739 \\
\hline Functionality_gov_structures_1 & -0.443 & -0.626 & -0.910 & -0.589 \\
\hline Regulation_foreign_trade_1 & 0.862 & 0.948 & 0.597 & 0.713 \\
\hline 2_Impact_external_factors_on_firm_1 & -0.495 & -0.714 & -0.952 & -0.615 \\
\hline Economic_policy_1 & -0.412 & -0.639 & -0.903 & -0.528 \\
\hline Bureaucracy_1 & -0.770 & -0.952 & -0.885 & -0.750 \\
\hline Corruption_1 & -0.765 & -0.953 & -0.881 & -0.739 \\
\hline Economic_crime_1 & -0.653 & -0.861 & -0.952 & -0.705 \\
\hline Efficiency_State_Gov_1 & -0.717 & -0.924 & -0.903 & -0.708 \\
\hline Price_stability_1 & -0.576 & -0.802 & -0.943 & -0.674 \\
\hline Exchange_rate_stability_1 & 0.212 & 0.349 & 0.013 & -0.016 \\
\hline Financial_resources_1 & 0.856 & 0.747 & 0.219 & 0.656 \\
\hline Infrastructure_1 & 0.815 & 0.829 & 0.354 & 0.601 \\
\hline Quality_availability_inputs_1 & -0.308 & -0.306 & -0.541 & -0.458 \\
\hline Reliability_bus_partners_1 & -0.385 & -0.634 & -0.936 & -0.520 \\
\hline 3_Impact_firm_on_environment_1 & 0.874 & 0.988 & 0.760 & 0.786 \\
\hline Fulfilling_vision_goals_1 & 0.894 & 0.976 & 0.668 & 0.770 \\
\hline Perform_productivity_profitability_1 & 0.842 & 0.837 & 0.373 & 0.643 \\
\hline Management_system_1 & 0.861 & 0.991 & 0.825 & 0.806 \\
\hline Investment_tech_development_1 & 0.842 & 0.983 & 0.833 & 0.791 \\
\hline Liquidity_cash-flow_1 & 0.879 & 0.960 & 0.639 & 0.749 \\
\hline Appeal_to_bus_partners_1 & 0.842 & 0.984 & 0.835 & 0.787 \\
\hline Employ_renum_soc_program_1 & 0.858 & 0.958 & 0.655 & 0.726 \\
\hline Natural_environment_1 & 0.810 & 0.954 & 0.911 & 0.817 \\
\hline Transp_public_perform_image_1 & 0.820 & 0.966 & 0.890 & 0.807 \\
\hline Charity_1 & 0.857 & 0.980 & 0.776 & 0.777 \\
\hline
\end{tabular}


Negative coefficients mean that despite the decline in the quality of the institutional environment in partial areas, the performance of business entities increases. This is referred to as a manifestation of institutional hysteresis. For a more detailed assessment of this phenomenon, we have used the regression analysis.

Tab. 5 - OLS model, using observations 2002-2016 (N = 15). Source: own processing by ŠÚ SR, 2017; PAS, 2017; MF SR, 2005; FS SR, 2017

\begin{tabular}{|l|l|l|l|l|}
\hline $\begin{array}{l}\text { Dependent vari- } \\
\text { able }(Y)\end{array}$ & $\begin{array}{l}\text { MODEL 1 } \\
\text { Employ_ } \\
\text { tHAC stand. } \\
\text { errors }\end{array}$ & $\begin{array}{l}\text { MODEL 2 } \\
\text { VA_milEUR }\end{array}$ & $\begin{array}{l}\text { MODEL 3 } \\
\text { RD_Corp_tEUR } \\
\text { HAC stand. } \\
\text { errors }\end{array}$ & $\begin{array}{l}\text { MODEL 4 } \\
\text { Corp_Tax_tEUR } \\
\text { OLS }\end{array}$ \\
\hline const & $\begin{array}{l}1829.74 * * * \\
(\mathrm{t}=15.50)\end{array}$ & $\begin{array}{l}15730.7 * * \\
(\mathrm{t}=2.833)\end{array}$ & $\begin{array}{l}335973 * * * \\
(\mathrm{t}=8.771)\end{array}$ & $\begin{array}{l}496417 \\
(\mathrm{t}=0.5825)\end{array}$ \\
\hline $\begin{array}{l}\text { Impact_external_ } \\
\text { factors_on_firm_ } \\
1 \text { (X) }\end{array}$ & $\begin{array}{l}1.06 \\
(\mathrm{t}=1.166)\end{array}$ & $\begin{array}{l}-19.46 \\
(\mathrm{t}=-0.575)\end{array}$ & $\begin{array}{l}-2404.65 * * * \\
(\mathrm{t}=-8.432)\end{array}$ & $\begin{array}{l}-3224.53 \\
(\mathrm{t}=-0.4850)\end{array}$ \\
\hline $\begin{array}{l}\text { Impact_firm_on_ } \\
\text { environment_1 } \\
\left(\mathrm{X}_{3}\right)\end{array}$ & $\begin{array}{l}1.79 * * * \\
(\mathrm{t}=7.954)\end{array}$ & $\begin{array}{l}200.60 * * * \\
(\mathrm{t}=15.26)\end{array}$ & $\begin{array}{l}200.07 * * \\
(\mathrm{t}=2.579)\end{array}$ & $\begin{array}{l}7191.65 * * * \\
(\mathrm{t}=4.531)\end{array}$ \\
\hline $\begin{array}{l}\text { Adjusted R- } \\
\text { squared }\end{array}$ & 0.76 & 0.97 & 0.91 & 0.56 \\
\hline F (2, 12) & 42.15 & 243.75 & 84.98 & 16.31 \\
\hline Durbin-Watson & 0.63 & 1.40 & 1.69 & 0.85 \\
\hline RESET test $(2,10)$ & 0.18 & 2.63 & 1.06 & 11.12 \\
\hline $\begin{array}{l}\text { White's test LM } \\
\text { (heteroskedastic- } \\
\text { ity) }\end{array}$ & 9.81 & 8.19 & 12.58 & 6.13 \\
\hline
\end{tabular}

Legend: Significance of marks (stars) by parameter's estimations *** - $99 \%$, ** _ $95 \%$, * $-90 \%$ probability.

Table 5 shows 4 multiple regression models to which we have selected as independent variables the aggregated subindeces of the BEI index, and we chose 4 macroeconomic and statistical data as dependent variables. Due to the occurrence of collinearity, we used only the 2nd and 3rd subindex.

Model 1 analyses the influence of independent variables on employment in the thousands of employee. The regression analysis explains $76 \%$ of input data based on the adjusted R-squared, according to F-statistics, the model is statistically significant, and according to Ramsey RESET test, is correctly specified. This means that there is no other independent variable that would significantly affect the model (the correct specification of the model was confirmed for 3 multiple regression analyses except model 4). The estimations of the variables support the correlation analysis results, which demonstrate statistically significant and logical dependence, especially among the components of the BEI in case of the third aggregate (The influence of our company 
on the quality of the business environment). Increasing this subindex by 1 point, we expect an increase in employment of approximately 1,790 employees with a $90 \%$ probability. Based on tstatistics, this estimate is accepted as statistically significant. The estimated parameters of the equation were influenced by the quality of the business environment measured by the BEI. The time series includes the pre-crisis, crisis and post-crisis periods, with the estimated parameters mitigating the extreme course of real values (2008 and 2010 to 2012). In this way we demonstrated a growing trend of employment in Slovakia which has not been distorted by the crisis phenomena. This rising trend was pulled only by the results of the third subindices, of which values grew proportionally to the number of employees in Slovakia. The model was estimated using robust standard errors (HAC) due to the presence of autocorrelation.

Model 2 analyses the influence of independent variable (BEI subindices) on value added. Value added is calculated by deducting the inter-consumption (at customer prices) from the gross production (at basic prices) of individual sectors, or industries. The value added does not include taxes reduced by subsidies on products. The results are based on outputs of statistical surveys for firms with 20 or more employees, for small enterprises with up to 19 employees and for tradesmen. They also contain data collected by the financial sector (ŠU SR, 2017). The regression analysis explains $97 \%$ of input data based on the adjusted R-squared. According to F-statistics, model 2 is statistically significant. The estimates of variables also support the results of the correlation analysis, which demonstrated a statistically significant and logical dependence mainly on the components of the BEI in case of the third aggregate (The influence of our company on the quality of the business environment). By raising this subindex by 1 point, we expect an increase in value added by approximately 200.6 mil. EUR. This estimate is also based on the statistically significant t-statistics.

All estimated parameters were statistically significant for model 3. Again, we had to use robust standard errors (HAC) because of the presence of autocorrelation and heteroskedasticity. Model 3 analyses the relations between expenditures on research and development and on the institutional environment. The hysteresis effect can be confirmed by a negative sign in the estimation of the variable 1 (The influence of other significant external macroeconomic factors on business). With the qualitative growth of this aggregate, we expected a paradoxical decrease in science and research expenditures based on the past developments. On the contrary, with the increase of the quality within subindex 3 (The influence of our company on the quality of the business environment), we expected an increase in the value of the dependent variable.

Model 4 has the lowest adjusted R-squared. Only $56 \%$ of the data is explained by the model. This model analyses the impact of the institutional environment on revenues from corporate taxes. The highest reporting ability is associated with the estimation of the parameter for subindex 3 . With an increase in this variable, we expected a rising trend of revenues from corporate taxes. The multiple regression analysis along with the correlation analysis confirmed our assumption that in the Slovak Republic a state of institutional hysteresis exists. We noted an improving trend of dependent variables which was supported only by the qualitative growth of the subindex Impact_firm_on_environment_1 (The influence of our company on the quality of the business environment). The other subindex identified the worsening state of the institutional environment. Based on the above, we consider that Slovak enterprises have undergone an adaptation process, 
and they are focusing mainly on strengthening internal competitiveness, maintaining liquidity and increasing investment in the production and internal enterprises potential.

As mentioned, BEI is a regional index that can be influenced by subjectivity. For this reason, the downward trend was verified by another supranational index, that of The Fraser Institute (2019). We divided the curve in graph 1 into two periods, with the first period representing 2000-2006, and the second period displaying 10 years of the last processed index data. For the second period, we applied the trend line in Excel and proved the deteriorating trend of economic freedom. It should be noted, however, that the results of the BEI index seem to us to be much more pessimistic.

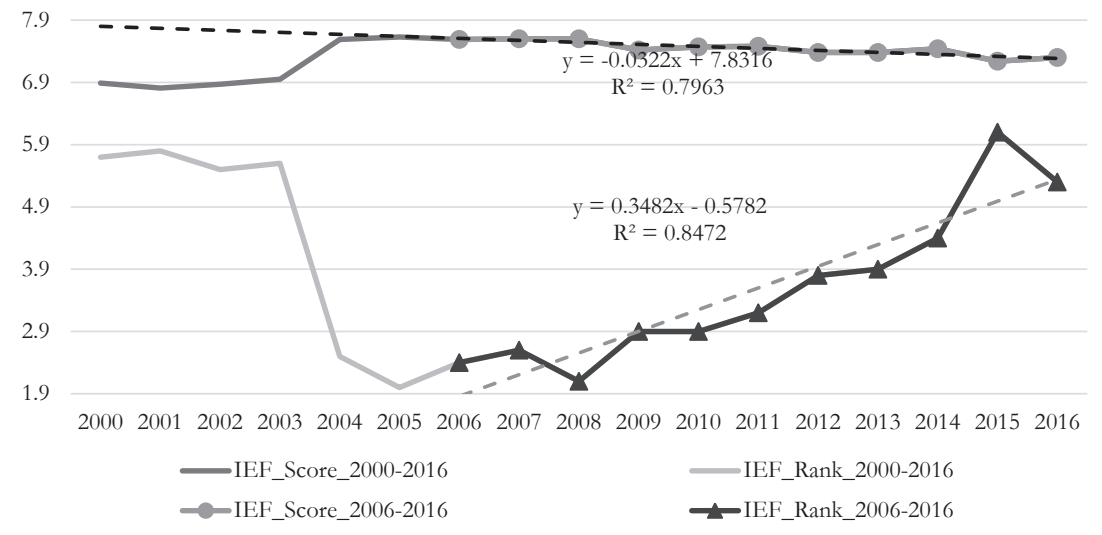

Fig. 1 - The Fraser Institute Economic Freedom. Source: own processing by The Fraser Institute (2018)

According to the author Pavelková et al. (2009 in Kozubikova, et al., 2019): “SMEs are of a great importance for the world economy because they promote competitive dynamics of economic systems and directly or indirectly affect large companies, especially in the fields of efficiency growth and innovations' development." Small and medium-sized enterprises have become an increasingly important component of economic development, representing a substantial proportion of national economies all around the world (Karpak \& Topcu, 2010). In this context, Henderson and Weiler (2010) indicate that SME can be characterized as a major engine of economic growth. Enterprises are influenced by business environment, including political, technological, economic, social and other factors, and especially by the quality of these determinants (Belás et al., 2014; Hudakova et al., 2018; Kozubikova et al., 2019; Torkkeli et al., 2019; Veliu et al., 2018). The business environment and its quality is currently a frequently researched and discussed topic. State and non-state institutions should focus on this aspect, as the perception of environment and quality also affects the motives and willingness of entrepreneurs and investors to enter the business sphere. At the same time, it is important to note that the quality of the business environment is also affected by the enterprises themselves. 


\section{CONCLUSION}

The objective of this paper was to verify the assumption that macroeconomic indicators in the Slovak Republic are improving with the process of institutional hysteresis despite the deterioration of the institutional environment in many areas. Entrepreneurs are guided by what is called in economic theory rational expectations. This theory has been elaborated on e.g. by Goutsmedt (2018), who is listed among the great authors' portfolio. The subject of our article is not this economic theory, so we recommend that readers also become familiar with the concept of rational expectations. For our needs, it is interesting that economic operators subordinate their actions to future expectations.

Rationally thinking entrepreneurs react not only to the current situation, but also consider the impact of intended future changes if they are familiar with them. In an environment with a high degree of uncertainty, and where measures to change business conditions can be taken in the short term, entrepreneurs become more cautious and less willing to invest in larger or longer-term projects, which are major drivers of the economic growth. On the contrary, such an environment favors speculative investments, particularly investments by individuals or narrow groups, which, unlike other participants, either already have information or are able to access information about intended measures to be taken in the future. This significantly influences their acceptance or non-acceptance of new projects.

We explain our conclusions in the light of the new institutional economic theory and transaction cost theory. A country with a better environmental rating should achieve lower transaction costs. Similarly, an economy with lower transaction costs should then achieve higher macroeconomic performance. We applied a correlation and regression analysis to the Slovak Republic and examined the relationship between the business environment index (BEI) variables and macroeconomic indicators. To our surprise, we found that almost the level of all external factors, such as law enforcement, is falling, and on the other hand, the macroeconomic indicators of the country are growing. Our hypothesis was that with a better assessment of the institutional environment through BEI (with the concurrent expected decline in transaction costs in the economy), we expected an improvement in employment, added value, science and research expenditures as well as an increase in revenues to the state budget from corporate taxes of the Slovak Republic. In the end we rejected this hypothesis.

Results in almost the entire BEI sub-index, which expresses the impact of business itself on the environment, innovation and the financial situation, have grown. From this state we concluded that companies in Slovakia had to have adapted to the bad external business environment, thus a state of institutional hysteresis occurred. We hope that the Slovak government is taking positive steps to improve the institutional environment, but we would like to express caution that, in accordance with the path dependence effect, any reform would require a relatively long time to show positive results.

The limitation of our research is primarily the small number of observations (BEI has been evaluated since 2001). As a dependent variable, this employment-based and R\& D model showed an autocorrelation or heteroskedasticity. For this reason, we have applied the robust standard errors (HAC) method instead of least squares (OLS). Although we could have used an autoregres- 
sive model, this approach would still reduce the number of observations. These factors reduced the level of quantitative analysis of the study. Another limitation is that BEI is evaluated on the basis of a questionnaire survey (and thus results could be distorted by e.g. political preferences or sentiment of entrepreneurs). This is a serious criticism. In a similar context, Coduras \& Autio (2013) claim that: "The main criticism of the NES [National Experts Survey] methodology is about the validation of experts' surveys and about the subjective character of the collected information on the entrepreneurial context. In its defense, it is possible to argue that expert's surveys are used and accepted by several economic and social projects to assess the state of different contexts, when there are no other objective sources of information [...]" This disadvantage could pose a challenge for further research for other authors along with a space for comparison with other measuring instruments.

As for further research, we recommend monitoring the changes in BEI, as the number of possible observations will increase. Furthermore, based on the knowledge of the state of the institutional environment, we recommend attempting to overcome the effects of institutional hysteresis and to formulate specific reform recommendations for the decisive sphere.

The above-mentioned factors have also been partly reflected in the results of our analysis. The longer the deformities of the institutional environment continue, the more they will be considered normal. The process of improving assessments of the country (corruption, law enforcement, equality before the law, functioning of the judiciary) will become much more expensive over time. The result of this change should be an entrepreneurial environment in which the entrepreneur does not have to deal with the ongoing optimization of taxes and levies, a condition which in the long run would lead to the economic recovery in Slovakia and improvements in competitiveness.

\section{Acknowledgement:}

The authors are grateful to Ing. Tatiana Hlušková, $\mathrm{PhD}$. for her professional consultation and discussion, to the Journal of Competitiveness editors and reviewers for feedback, advice and recommendations.

\section{References}

1. Belás, J., Bartoš, P., Habánik, J., \& Novák, P. (2014). Significant Attributes of the Business Environment in Small and Medium-Sized Enterprises. Economics and Sociology, 7 (3), 22-39. http://dx.doi.org/10.14254/2071-789X.2014/7-3/2

2. Coduras, A., \& Autio, E. (2013). Comparing subjective and objective indicators to describe the national entrepreneurial context: The Global Entrepreneurship Monitor and the Global Competitiveness Index contributions. Investigaciones Regionales, 26 (1), 47-74.

3. Eling, M., \& Schaper, P. (2017). Under pressure: how the business environment affects productivity and efficiency of European life insurance companies. European Journal of Operational Research, 258 (3), 1082-1094. https://doi.org/10.1016/j.ejor.2016.08.070

4. FS SR. (2017). Plnenie štátneho rozpočtu. Retrieved October, 3, 2017, from https://www. financnasprava.sk/sk/infoservis/statistiky/plnenie-statneho-rozpoctu.

5. GOUTSMEDT, A. (2018). Thomas Sargent Facing Robert Lucas: Another Ambition for New Classical Economics. OEconomia, 8 (2), 211-241. https://doi.org/10.4000/ oeconomia. 3047 
6. Harc, M., \& Basarac Sertic, M. (2016). The Influence of the Business Environment on the SMEs Employment in the EU 28. Interdisciplinary Management Research XII. Opatija, 12. Available at: https://zebrica.app.box.com/s/iz0uukl0iufa6u505hpoihulp0lhxexj

7. Henderson, J., \& Weiler, S. (2010). Entrepreneurs and job growth: probing the boundaries of time and space. Economic Development Quarterly, 24 (1), 23-32. https://doi.org/10.1177/089 1242409350917

8. Hudakova, M., Masar, M., Luskova, M., \& Patak M.R. (2018). The Dependence of Perceived Business Risks on the Size of SMEs. Journal of Competitiveness, 10 (4), 54-69. https://doi. org/10.7441/joc.2018.04.04

9. Karpak, B., \& Topcu, I. (2010), Small and medium manufacturing enterprises in Turkey: an analytic network process framework for prioritizing factors affecting success. International Journal of Production Economics, 125 (1), 60-70. https://doi.org/10.1016/j.ijpe.2010.01.001

10. Kittová, Z., \& Steinhauser, D. (2017). Inštitucionálne a makroekonomické prostredie firiem. Politická ekonomie, 65 (2), 234-248. https://doi.org/10.18267/j.polek.1138

11. Kozubikova, L., Kotaskova, A., Dvorsky, J., \& Kljucnikov, A. (2019). The Impact of Political Factors' Perception on Suitability of International Business Environment: The Case of Startups. Economics \& Sociology, 12 (1), 61-79. https://doi.org/10.14254/2071789X.2019/12-1/3

12. Liška, V., Sluková, K., \& Volejníková, J. (2011). Institucionálni ekonomie. Praha: Professional Publishing.

13. Lukáčik, M., Lukáčiková, A., \& Szomolányi, K. (2011). Ekonometrické modelovanie v programoch EViews a Gretl. Bratislava: Ekonóm.

14. Martincová, M. (2005). Nezamestnanost' ako makroekonomický problém. Bratislava: IURA Edition.

15. MF SR. (2005). Denný prehlad o plnení vybraných ukazovatelov štátneho rozpočtu za mesiac december 2005. Retrieved October, 3, 2017, from http://www.mfsr.sk/Default. aspx?CatID $=4766$

16. Nguimkeu, P. (2016). Some effects of business environment on retail firms. Applied Economics, 48 (18), 1647-1654. https://doi.org/10.1080/00036846.2015.1105923

17. Okruhlica, F. (2013). Výška transakčných nákladov ako meradlo kvality podnikatel’ského prostredia v Slovenskej republike a Českej republike. In Majtán, Š. et al. Aktuálne problémy podnikovej sféry. Bratislava: Ekonóm, 434-439.

18. Pacáková, V. et al. (2009). Štatistické metódy pre ekonómov. Bratislava: IURA Edition.

19. PAS. (2013). Index podnikatel'ského prostredia. In Conorto, R. et al. (2014). Analýa, monitor kvality podnikatel'ského prostredia v SR a konkurencie schopnost' ekonomiky. Retrieved October, 3, 2017, from http://www.azzz.sk/wp-content/uploads/2015/05/Anal\%C3\%BDza-monitorkvalitypodnikate $\% \mathrm{C} 4 \% \mathrm{BEsk} \% \mathrm{C} 3 \%$ A 9 ho-prostredia-v-SR-a-konkurencieschopnos $\% \mathrm{C} 5 \%$ A5-ekonomiky.pdf?x94703

20. PAS. (2017). Index podnikatel'ského prostredia. Retrieved October, 3, 2017, from http:// alianciapas.sk/wp-content/uploads/2017/02/IPP-2016-4-open.xlsx 
21. Pavelková, D. et al. (2009). Klastry a jejich vliv na výkeonnost firem. Praha: Grada.

22. Rialp-Criado A. \& Komochkoya, K. (2017). Innovation strategy and export intensity of Chinese SMEs: the moderating role of the home-country business environment. Asian Business \& Management, 16 (3), 158-186. https://link.springer.com/article/ 10.1057\%2Fs41291-017-0018-2

23. Schwab, K., \& World Economic Forum. (2018). Global Competitiveness Report 2018. Retrieved May, 18, 2019, from http://www3.weforum.org/docs/GCR2018/05FullReport/ TheGlobalCompetitivenessReport2018.pdf

24. Steinhauser, D. (2015). Measuring the quality of the institutional environment through the development of prices of credit default swaps in times of economic disturbances. Investment Management And Financial Innovations, 12(4), 98-105.

25. ŠÚ SR. (2017b). Slovstat. Retrieved November, 3, 5 and 10, 2017 from http://www. statistics.sk/pls/elisw/casovy_Rad.procDlg; http://www.statistics.sk/pls/elisw/objekt. send?uic $=988 \& \mathrm{~m} \_$sso $=3 \& \mathrm{~m} \_$so $=81 \& \mathrm{ic}=36 ; \mathrm{http}: / / \mathrm{www} . \mathrm{statistics.sk} / \mathrm{pls} / \mathrm{elisw} / \mathrm{katalog}$. listObj?objekt $=3549$

26. The Fraser Institute. (2019). Economic Freedom 2018 - Data for Researcher. Retrieved May, 20, 2019 from https://www.fraserinstitute.org/sites/default/files/efw-2018-masterindex-data-for-researchers.xlsx

27. Torkkeli, L., Kuivalainen, O., Saaranketo, S., \& Puumalainen, K. (2019). Institutional environment and network competence in successful SME internationalisation. International Marketing Review, 36 (1), 31-55. https://doi.org/10.1108/IMR-03-2017-0057

28. Trung, N. B., \& Kaizoji, T. (2017). Investment climate and firm productivity: an application to Vietnamese manufacturing firms. Applied Economics, 49 (44), 4394-4409. https://doi. org/10.1080/00036846.2017.1282148

29. Veliu, L., Manxhari, M., Podvorica, N., Fejza, E., \& Hyesni, V. (2018). Managing SMEs in a turbulent context: A case study from a Kosovan manufacturing company. Journal of Competitiveness, 10 (1), 155-170. https://www.cjournal.cz/files/281.pdf

30. Wallis, J., \& North, D. (1986). Measuring the Transaction Sector in the American Economy, 1870-1970. In Long-Term Factors in American Economic Growth: NBER book (pp. 95-162). University of Chicago Press. Retrieved from https://www.nber.org/chapters/c9679

31. Wang, N. (2003). Measuring Transaction Costs: An Incomplete Survey (Working Paper No. 2). Retrieved from Ronald Coase Institute Working Papers website: https://www.coase. org/workingpapers/wp-2.pdf

32. WBG. (2017). Doing Business - Business Reforms in the Slovak Republic. Retrieved November, 8, 2017, from http://www.doingbusiness.org/Reforms/Overview/Economy/ slovakia

33. Williamson, O. E. (1990). The Economic Institutions of Capitalism. New York: The Free Press 1985; German translation (M. Streissler, transl.). Die ökonomischen Institutionen des Kapitalismus. Tübingen: Mohr Siebeck. 


\section{Contact information}

Ing. Ladislav Bazo, PhD.

University of Economics in Bratislava

Faculty of Commerce

Department of Services and Tourism

Slovakia

E-mail: ladislav.bazo@euba.sk

Ing. Miroslava Cukanova, PhD.

University of Economics in Bratislava

Faculty of Commerce

Department of Services and Tourism

Slovakia

E-mail:miroslava.cukanova@euba.sk

ORCID: 0000-0002-7767-2353

Ing. Laura Markovicova, PhD.

University of Economics in Bratislava

Faculty of Commerce

Department of Services and Tourism

Slovakia

E-mail:markovicova.laura@gmail.com

Ing. Dusan Steinhauser, PhD.

University of Economics in Bratislava

Faculty of Commerce

Department of International Trade

Slovakia

E-mail:dusan.steinhauser@euba.sk

ORCID: 0000-0003-0708-9020 